Status Report 2016-2019

\title{
Tectonics of the Deccan Trap: Focus on Indian Geoscientists' Contribution in the Last Four Years
}

\author{
SOUMYAJTT MUKHERJEE ${ }^{1 *}$, GAURI DOLE ${ }^{2}$, VADAKKEYAKATH YATHEESH $^{3}$ and VIVEK S KALE \\ ${ }^{1}$ Department of Earth Sciences, Indian Institute of Technology Bombay, Powai, Mumbai 400076 , \\ Maharashtra, India \\ ${ }^{2}$ Department of Environmental Science, Savitribai Phule Pune University, Pune 411 007, Maharashtra, \\ India \\ ${ }^{3}$ CSIR-National Institute of Oceanography, Dona Paula, Goa 403 004, India \\ ${ }^{4}$ Advanced Center for Water Resources Development and Management (ACWADAM), Pune, 411058 , \\ Maharashtra, India
}

(Received on 20 August 2019; Accepted on 10 September 2019)

\begin{abstract}
In the Deccan Trap, the west coast around Mumbai is presently designated as a "sheared margin" with nearly N-S trending strike-slip brittle shears. The eastern part of the Deccan trap shows prolific conjugate strike-slip faults. Tertiary and Quaternary reactivations of the sub-Trappean discontinuities had a geomorphologic implication since they modified the Deccan drainage systems. The marine geophysical investigations carried out in the western offshore regions have yielded a detailed understanding of the role of Deccan volcanism on the India-Seychelles-Madagascar breakup and the subsequent formation and evolution of the Western Indian Ocean. The revised plate tectonics takes care of the microcontinental slivers and the extinct spreading centers. The fossil Gop-Narmada-Laxmi Triple Junction was initiated by the earliest manifestation of the Deccan volcanism $\sim 68.5 \mathrm{Ma}$. The Western Indian Ocean depicts a sharp drop in the spreading rate at around chron $\mathrm{C} 28$ no ( $63.63 \mathrm{Ma})$, soon after the main pulse of the Deccan volcanism. Based on the correlation of estimated ${ }^{40} \mathrm{Ar} /{ }^{39} \mathrm{Ar}$ ages for the onshore Ghatkopar-Powai tholeiites and the inferred age of the Raman-Panikkar-Wadia seamount chain in the Laxmi Basin, both these features are interpreted to represent the volcanic emplacement coeval to the Deccan volcanism at $\sim 62.5 \mathrm{Ma}$.
\end{abstract}

Keywords: Large Igneous Province; Secondary Structures; Igneous Flow-Tectonics Interaction; Deformation Mechanism

\section{Introduction}

The (sub)horizontal stratification of the basaltic flows that can be traced across several tens of $\mathrm{km}$ led to the erstwhile conclusion that the Deccan Volcanic Province (DVP; Fig. 1) is a tectonically stable, structurally undisturbed terrain of Peninsular India. Its current geomorphology was attributed to continental-scale isostatically driven cycles of uplift. The advent of remote sensing and global digital terrain data, modern computing techniques, and focused software solutions provided a fascinating platform for assessing the morphological evolution of terrains. Drainage anomalies in this terrain recorded through a quantitative geomorphic analysis were ascribed to Quaternary climate changes rather than the structural controls or the neotectonic activity. The different subprovinces of the Deccan trap viz., Saurashtra (+Kutch), Malwa Plateau, Amarkantak Plateau, Satpura and Deccan Plateau presumably have distinct eruptive histories (Kale, 2020). The structural features such as the Panvel flexure (Samant et al., 2017) were linked with the eruptive history of the Deccan Traps during the passage of the Indian plate over the Rèunion hotspot and its separation from Madagascar and Seychelles (Misra et al., 2014).

*Author for Correspondence: E-mail: soumyajitm@gmail.com 


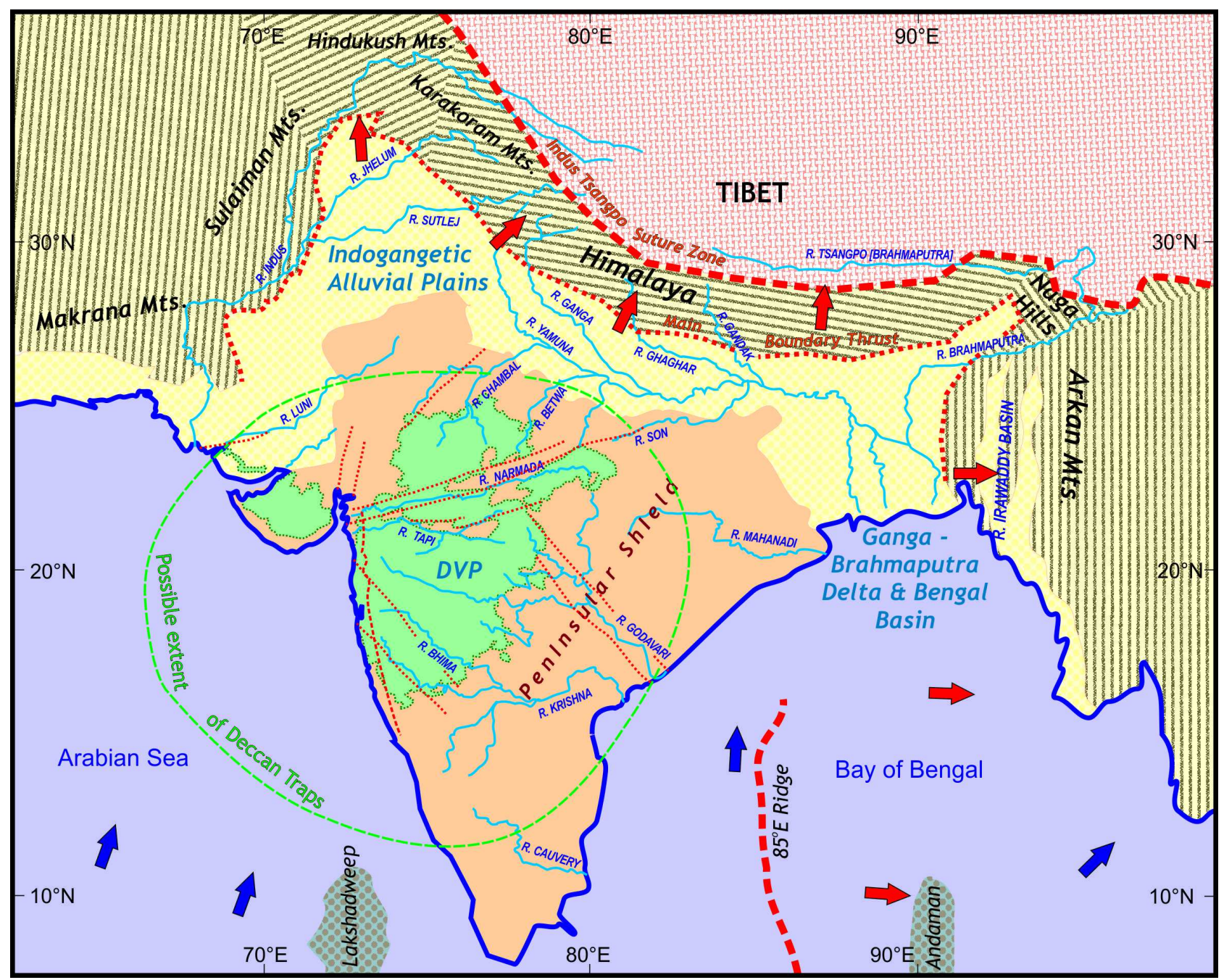

Fig. 1: Generalized tectonic map of the Indian subcontinent showing major tectonic units. The Indo-Gangetic alluvial plains represent the Quaternary alluvial plains. Orange shaded area: Indian Peninsular Shield, capped in the west-central parts by the green shaded DVP. Dashed green line: postulated outer limits of the DVP. Red dashed lines: major active zones of structural heterogeneity. Red arrows: the direction of plate movement. Blue arrows: the plate movement driven by ocean floor spreading of the Indian Ocean

\section{Structures and Tectonics}

Based on seismic image interpretation and gravity studies, Misra et al. (2015) decipher that the Laxmi Ridge is composed of high-density oceanic crust. Radha Krishna et al. (2002) conclude that the Laxmi ridge is underlain by continental crust up to $11 \mathrm{~km}$ depth, and there exists a dense rock $\left(3.0 \mathrm{~g} \mathrm{~cm}^{-3}\right)$ between $11-26 \mathrm{~km}$. A stretching factor $(\beta)>3.0$ is estimated from the lithosphere below the Laxmi-Gop basin region by Rao et al. (2018), and they interpret this as an outcome of extension either since IndiaMadagascar rifting or even much before. Recent gravity studies of the DVP document its lithosphere at the NW part is thinner. Mitra et al.'s (2015) geochemical studies reveal the smectite and kaolinite variations related to the faults bounding the Matanomadh Basin (Gujarat). They deciphered a Cenozoic rifting-induced palaeoslope.

Misra et al. (2017) study subsidence on the ridges in the NW Arabian Sea and seismic carbonate facies to analyze the role of the Deccan mantle plume in the tectonics of the offshore DVP. Gupta et al. (2017) use multiple geophysical techniques in the Koyna region to explain the seismicity induced by cyclic loading and unloading of water in the artificial reservoirs since 1967 (also see Gupta et al., 2015). 
Borehole investigations by these authors reveal weak planes, viz., foliation planes, and faults. Sarkar and Saein (2017) highlight the need for doing new seismic studies to constrain faults in the Koyna region better. Subbarao and Courtillot (2017) question the tectonic significance of the triangular fracture set in the Warna region. Kumar and Dixit (2017), based on local earthquake tomography document a $\sim 5 \mathrm{~km}$ wide and 3-7 km deep seismic cluster south of the Warna region. Patro et al. (2017), based on ground electrical and electromagnetic studies, deduce the thickness variation of the Deccan trap lava around the Koyna region. A similar approach by Patro et al. (2018) reveals the same in other parts of the western Ghat as well. The P-wave receiver functions enable Mandal (2017) to delineate the crust-mantle structure below the rift zone in the Kutch region, which he links with the lowercrustal seismicity. Rajaram et al. (2017) identify seven sub-surface lineaments in part of the Deccan Trap region based on the magnetic study. These lineaments are linked by them with the brittle shear zones, faults and river courses. The work can have a far-reaching implication since these lineaments can lead to the identification of blind faults/shear zones/ sediment-filled basins. Maurya et al. (2017) present the neotectonic roles of the active faults in the Kutch region. The work is relevant in the present-day seismicity and inversion of the Kachchh basin.

Interestingly, Maurya et al.'s (2017) groundpenetrating radar studies document a few blind faults as well. Using borehole image logs, Chatterjee et al. (2017) document typical fracture patterns from the basement of the Cambay basin, which is the Deccan trap rock. Kaotekwar et al. (2014) detail the primary volcanic structures from the Deccan basalts at Anantagiri Hills (Andhra Pradesh).

Several papers have come up related to the field interpretation of dykes from the DVP in the last few years. The structural field studies by Misra and Mukherjee (2017) reveals differences in the structural deformation of different age groups of basaltic dykes in the province. An older c.65.5 Ma group of dykes (Group I) are faulted and lack a uniform trend. Younger c.65-63 Ma Group II and Group III dykes are syn- to post-deformation intrusions and intrude into the faults. The authors point out that, in addition to the dyke trends, the direction of the Seychelles India separation can also be studied from the attitude of the brittle shear planes exposed in the coastal region of the Deccan Trap.

Based on detail geomorphologic studies, Kaplay et al. (2017a) interpret neotectonic signatures around the city Nanded near the eastern extremity of the Deccan trap in the state Maharashtra. Interestingly, the numerical model of Yadav and Tiwari (2018) reveals 20-25 MPa magnitude of the present-day NNE-oriented stress active in the Deccan trap. Neotectonic activities in the Deccan trap, therefore, seems plausible. The other signature of neotectonics is landslides, which have an additional constraint of erosion around the Mahabaleshwar area (Joshi et al. 2018). A neotectonic role of slides in the Kalsubai region cannot be ruled out (Gawali et al. 2017). Kaplay et al. (2017b) report dykes from the Kinwat region in the eastern part of the Deccan Traps. Based on the occurrence of faults and lineaments, the authors consider Kinwat to be a future location of intra-plate seismicity. Babar et al. (2017) report brittlesheared NE-trending dykes from the Aurangabad region that match the trend of the Narmada - Tapti lineament. They also report from the field the local directions of lava flows. The NW part of the DVP has been geophysically proved to have significantly altered crustal and mantle structure due to the Deccan volcanism (Deshpande and Mohan 2016).

Recently, mapping of flow layers and field studies by Bhave et al. (2017) reveal an NW-trending Sutawardi Fault Zone with reverse faulting, traceable for $\sim 5 \mathrm{~km}$, around the Koyna-Warna seismic zone. This fault needs further studies to find its relevance in the Deccan tectonics.

From the Saurashtra region (Gujarat), Vanik et al. (2018) identify multiply activated, brittle, localized, reverse, oblique-slip Katar fault with a sinistral slip component near the location Rajula/Katar. Very detail fault slip analyses by these authors conclude that the Katar Fault is a post-Deccan trap oblique-slip reverse fault with a sinistral slip component arising due to the movement of the Indian plate. High-velocity seismic anomalies reaching up to the Moho in the Saurashtra region probably indicates the intrusives related to the Deccan Traps (Prajapati et al. 2016). Mishra et al. (2017) and Sinha et al. (2017) detail the structural geology (fractures, faults, conjugate joints, gouge, and breccia) to some extent from the basement rocks located at the Koyna deep drilling site. 


\section{Structurally Affected zones: Few Specific Regions}

\section{Konkan Coastal Belt}

Westward dips have been recorded in the basaltic flows and intertrappeans along this belt associated with the Panvel flexure in the northern parts of the Konkan Coastal Belt (Dessai and Bertrand, 1995; Misra et al., 2014). In the southern regions, several NW-SE trending faults/shear zones have been recorded (Kale et al., 2014; Arora et al., 2018) that affected presumably not just the Deccan basalts but also the capping lateritic cover and the basement of the Deccan Traps. The recent studies related to the Koyna-Warna Seismic zone suggest that the NWSE trending Chiplun lineament (Kale et al., 2014) may have a close connection with the ongoing seismic activity in the zone; and that it is a reactivated basement shear (Arora et al., 2018). This compares well with the emerging models that many of the deformation zones in the DVP represent reactivated basement zones of weakness having a long history of episodic tectonics (Peshwa and Kale, 1997; Kale et al., 2017).

\section{Narmada Valley}

Different blocks of crust across the length of the Narmada river uplifted/subsided differentially in the post-Trappean times. This is further supported by geological and geophysical observations (Ravi Kumar et al., 2015; Valdiya, 2016; Kumar et al., 2019). The dyke swarms along the Narmada river indicate that the river trace is one of the foci of the eruption of the Deccan Traps (Shrivastava et al., 2017). The interpretation of geophysical data (Ravi Kumar et al., 2015; Kumar et al., 2019) of the $>52 \mathrm{~km}$ thick crust along the Narmada-Tapi belt as against its flanks (reducing to $<40 \mathrm{~km}$ ) requires significant field data to understand the evolution of the valleys of the two (anomalously) westerly flowing rivers, the Narmada and Tapi and the Satpura belt between them. Lack of data and studies along this zone renders ambiguity in the existing models of this region as a horst, graben, or otherwise (Sheth, 2018; Kumar et al., 2019).

\section{Western Ghats Escarpment/Sahyadri Ranges}

These features suggest that neotectonic differential uplift can explain the current morphometric set up on the flanks of the WGE (Kale et al., 2017) and the downstream topography in the Deccan Plateau.

\section{Deccan Trap in the Indian Western Offshore}

The western continental margin of India and the adjacent deep ocean basins containing the imprints of rifting and the subsequent evolution are further affected by several major geodynamic events, e.g., the Marion and the Rèunion hotspots volcanisms at $\sim 88 \mathrm{Ma}$ and $\sim 65-66 \mathrm{Ma}$ (Storeyet al., 1995; Courtillot et al., 1988), extinction of spreading centers at $\sim 60.25$ Ma and $~ 56.4 \mathrm{Ma}$ (Bhattacharya and Yatheesh, 2015; Shuhail et al., 2018), ridge jumps at $\sim 63 \mathrm{Ma}$ (Misra et al. 2015) and the India-Eurasia collision initiated at $\sim 52 \mathrm{Ma}$.

\section{Revised Plate Tectonic Evolution Model for the Western Indian Ocean (88.0 to 56.4 Ma)}

Bhattacharya and Yatheesh (2015) review all the available constraints and utilized their data to provide a revised and updated plate tectonic evolution model for the Western Indian Ocean between 88 to 56.4 Ma. They conclude that the most reasonable interpretation of age in the Laxmi and the Gop basins represent the magnetic anomaly sequences of $\mathrm{C} 30 \mathrm{n}-$ $\mathrm{C} 25 \mathrm{r}-\mathrm{C} 30 \mathrm{n}$ (67.6-56.4 Ma) and C29r-C25r-C29r ( $64.8-56.4 \mathrm{Ma})$, respectively. In both the basins, these identifications suggest a drop in the half spreading rates after the time of the peak of Deccan Flood Basalt volcanism, and there will not be much difference in the ages of the Laxmi and the Gop basin regimes. Shuhail et al. (2018) attempt to improve this model to depict the formation and evolution of conjugate tectonic elements from the SW continental margin of India and SE continental margin of Madagascar. This revised model also suggests a sharp drop in the half spreading rate during the evolution of the Mascarene Basin at around C28no ( 63.63 Ma), i.e., soon after the peak of the Deccan Flood Basalt volcanism. This timing nearly coincides with a sharp drop of spreading rates observed in the Laxmi and the Gop basins and the opening of the conjugate Arabian and Eastern Somali basins between the Laxmi Ridge and the Seychelles Plateau.

\section{Correlation of Onshore-offshore Deccan Volcanism}

Pande et al. (2017) carry out a geochronologic investigation on the tholeiitic flows and dykes in the Ghatkopar-Powai area located in the structurally disturbed Panvel flexure zone on the Indian mainland. Dating of these seaward dipping pre-flexure flows 


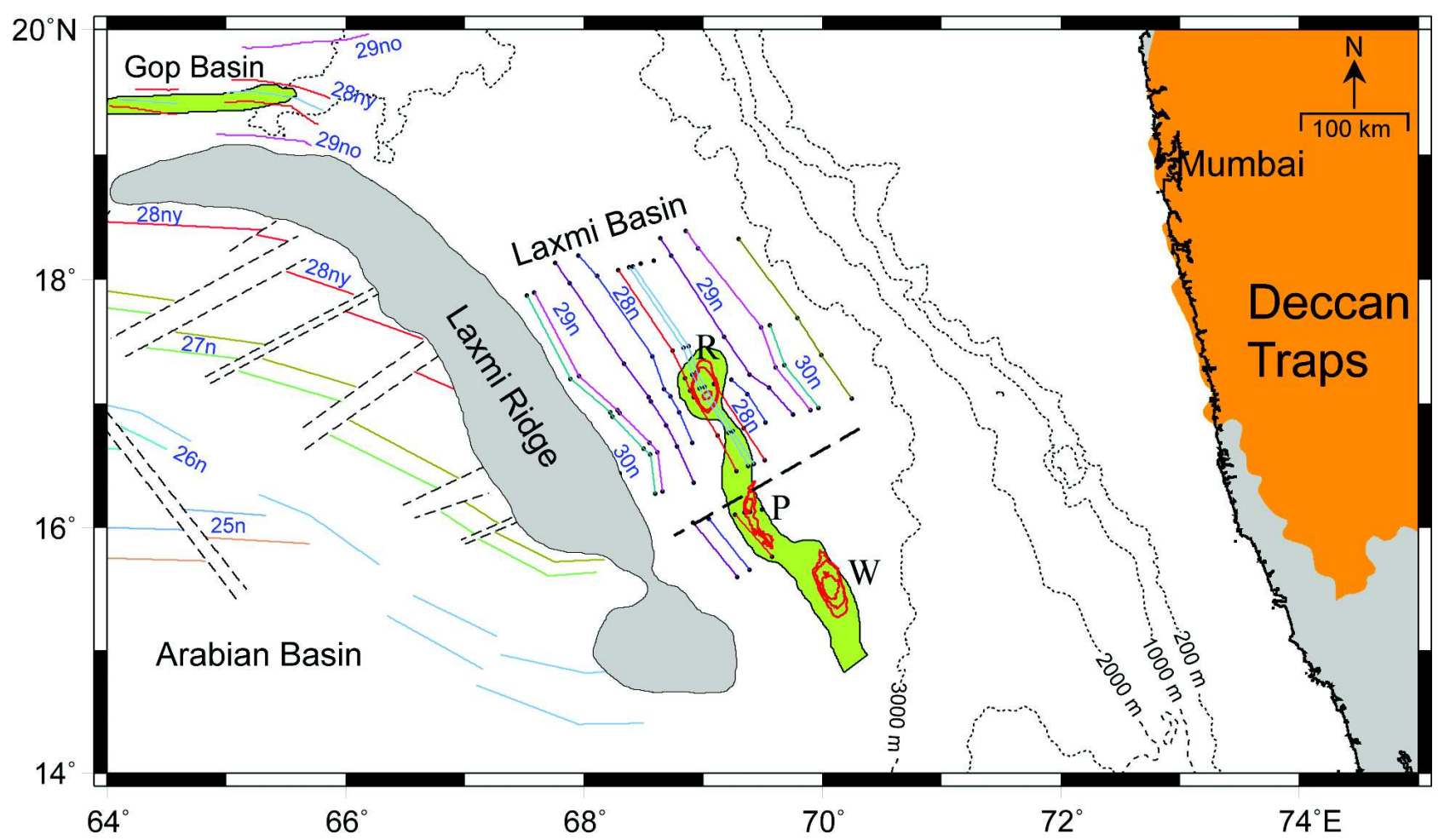

Fig. 2: Tectonic setting of the deep offshore regions adjacent to the western continental margin of India (modified after Bhattacharya and Yatheesh, 2015 and Pande et al., 2017). R: Raman Seamount; P: Panikkar Seamount; W: Wadia Guyot

and the sub-vertical post-flexure dykes yield ${ }^{40} \mathrm{Ar} /$ ${ }^{39} \mathrm{Ar}$ ages of $62.5 \mathrm{Ma}$, indicating that the Panvel flexure has formed very rapidly and instantaneously at $62.5 \mathrm{Ma}$. Since the age of $62.5 \mathrm{Ma}$ has significance in terms of the tectonic events occurred in the deep offshore regions adjacent to the western continental margin of India, they correlate the $62.5 \mathrm{Ma}$ old onshore-offshore magmatism with the India-Laxmi Ridge-Seychelles breakup. One major coeval event is the onset of seafloor spreading between the Laxmi Ridge and the Seychelles Plateau that created the conjugate Arabian and the Eastern Somali basins. This inference was based on the oldest magnetic lineation representing the chron C28ny (62.5 Ma) identified from the Arabian Basin (Laxmi Ridge side) and the Eastern Somali Basin (Seychelles side). Pande et al. (2017) infer that the onshore emplacement of the Ghatkopar-Powai tholeiitic flows, the dykes and the offshore emplacement of the Raman-Panikkar-Wadia seamount chain formed coevally to an intense phase of Deccan volcanism $\sim 62.5 \mathrm{Ma}$.

\section{Laccadive Basin and Surroundings}

Bijesh et al. (2018) carry out a detailed marine geophysical investigation over the bathymetric high features located in the southwestern continental margin of India, Laccadive Basin, andthe eastern sector of the Laccadive Plateau. They infer the detailed morphological characteristics of all these features and create a database with the derived morphometric parameters.

\section{The Offshore Extent of the Deccan Flood Basalt}

The size of the Deccan Flood Basalt on the Indian mainland has been mapped in detail by field geologists. However, its offshore size is poorly constrained geophysically. This is probably due to the unavailability of adequate marine geophysical data and the lack of an appropriate approach to determine the flood basalt. Kumar and Chaubey (2019) attempted to delineate the offshore extent of the Deccan Flood Basalt using the P-wave velocity in flood basalt $\left(4.2-5.2 \mathrm{~km}^{-1}\right)$ as a proxy, integrated with the drilled well results and the seaward dipping reflectors (SDRs). 


\section{Acknowledgments}

S M thanks, Profs. D M Banerjee and S Dasgupta to invite to write this article. G D thanks D S T for financial support under the Women Scientist Scheme.

\section{References}

Arora K, Srinu Y, Gopinadh D, Chadha R K, Raza H, Mikhailov V, Ponomarev A, Kiseleva E and Smirnov V (2018) Lineaments in the Deccan Basalts: the basement connection in the Koyna -Warna RTS region Bulletin of the Seismological Society of America 108 2919-2932

Babar Md, Kaplay R D, Mukherjee S and Kulkarni P S (2017) Evidences of deformation of dykes from Central Deccan Volcanic Province, Aurangabad, Maharashtra, India In: Mukherjee S, Misra AA, Calvès G and Nemèok M (Eds) Tectonics of the Deccan Large Igneous Province Geological Society, London, Special Publications 445 337-353

Bhattacharya G C and Yatheesh V (2015) Plate-tectonic evolution of the deep ocean basins adjoining the western continental margin of India - a proposed model for the early opening scenario, In Mukherjee S (Ed)Petroleum Geoscience: Indian Contexts. Springer International Publishing, Switzerland, pp. 1-61

Bhave N, Siddique M I, Desai J, Patil Pillai S, Dole G, Kulkarni H and Kale V S (2017) Faulting in Deccan Traps in the vicinity of Koyna-Warna Seismic Zone Journal of the Geological Society of India 6 748-751

Bijesh C M, John Kurian P, Yatheesh V, Tyagi A and Twinkle D (2018) Morphotectonic characteristics, distribution and probable genesis of bathymetric highs off the southwest coast of India Geomorphology 315 33-44

Chatterjee R, Datta Gupta S and Mandal P P (2017) Fracture and Stress Orientation from Borehole Image Logs: A Case Study from Cambay Basin, India Journal of the Geological Society of India $\mathbf{8 9}$ 573-580

Courtillot V, Feraud G, Maluski H, Vandamme D, Moreau M G and Besse J (1988) Deccan flood basalts and Cretaceous/ Tertiary boundary Nature 333 843-846

Deshpande AA and Mohan G (2016) Seismic evidence of crustal heterogeneity beneath the northwestern Deccan volcanic province of India from joint inversion of Rayleigh wave dispersion measurements and P receiver functions Journal of Asian Earth Sciences 128 54-63

Dessai A G and Bertrand H (1995) The "Panvel flexure' along the western Indian continental margin: an extensional fault
VY thanks the Director, CSIR-NIO for the permission to publish this article. V S K acknowledges financial support from DST and MoES vide completed projects, which have enabled field studies.

structure related to Deccan magmatism Tectonophysics $\mathbf{2 4 1}$ $165-178$

Gawali P B, Aher S P, Lakshmi B V, Gaikwad R D, Deendayal K, Hanamgond P T, Mahesh Babu J L V, Arote S A and Bairage S I (2017) Identification of landslide susceptible villages around Kalsubai region, Western Ghats of Maharashtra using geospatial techniques Journal of the Geological Society of India 90 301-311

Gupta H K et al. (2017) Investigations of continued reservoir triggered seismicity at Koyna, India In Mukherjee S, Misra A, Calvès G and Nemèok M (Eds) Tectonics of the Deccan Large Igneous Province Geological Society, Special Publications 445 151-188

Gupta H K et al. (2015) Investigations related to deep scientific drilling to study reservoir-triggered earthquakes at Koyna, India Intentional Journal of Earth Sciences 104 1511-1522

Joshi M, Rajappan S, Rajan P P, Mathai J, Sankar G, Nandakumar V and Kumar V A (2018) Weathering Controlled Landslide in Deccan Traps: Insight from Mahabaleshwar, Maharashtra Journal of the Geological Society of India 92 $555-561$

Kale V S (2020) Cretaceous volcanism in Peninsular India: Rajmahal - Sylhet \& Deccan Traps. In: Gupta N and Tandon S K (Eds) Geodynamics of the Indian Plate Springer. Nature DOI: 10.1007/978-3-030-15989-4

Kale V S, Dole G, Upasani D and Patil Pillai S (2017) Deccan Plateau uplift: insights from the Western Uplands, Maharashtra, India. In: Mukherjee S, Misra AA, Calvès G, Nemèok M (Eds) Tectonics of the Deccan Large Igneous Province Geological Society, London, Special Publications 445 11-46

Kaotekwar A B, Meshram R R, Sathyanarayanan M, Krishna A K and Charan S N (2014) Structures, Petrography and Geochemistry of Deccan Basalts at Anantagiri Hills, Andhra Pradesh Journal of the Geological Society of India $\mathbf{8 4}$ 675685

Kaplay R D, Babar Md, Mukherjee S and Kumar T V (2017a) Morphotectonic expression of geological structures in eastern part of southeast Deccan volcanic province (around Nanded, Maharashtra, India) In Mukherjee S, Misra AA, 
Calvès $G$ and Nemèok M (Eds) Tectonics of the Deccan Large Igneous Province Geological Society, London, Special Publications 445 317-335

Kaplay R D, Kumar T V, Mukherjee S, Wesanekar P R, Babar Md, and Chavan S (2017b) E-W strike-slip shearing of Kinwat Granitoid at South East Deccan Volcanic Province, Kinwat, Maharashtra, India Journal of Earth System Science $\mathbf{1 2 6} 71$

Kumar S and Dixit M M (2017) Three Dimensional Velocity Structure of the Koyna-Warna Region using Local Earthquake Tomography Journal of the Geological Society of India 90 690-697

Kumar P and Chaubey A K (2019) Extension of flood basalt on the northwestern continental margin of India Journal of Earth System Science 12881

Kumar P, Tewari H C and Sreenivas B (2019) Seismic structure of the Central Indian Crust and its implications on crustal evolution Journal of the Geological Society of India $\mathbf{9 3}$ 163-170

Mandal P (2017) Influence of Deccan volcanism/syn-rift magmatism on the crust-mantle structure and its implications for the seismogenesis of earthquakes occurring in the Kachchh rift zone In Mukherjee S, Misra A, Calvès $\mathrm{G}$ and Nemèok M (Eds) Tectonics of the Deccan Large Igneous Province Geological Society, London, Special Publications 445 189-218

Maurya D M, Chowksey V, Patidar A K and Chamyal L S (2017) A review and new data on neotectonic evolution of active faults in the Kachchh Basin, Western India: Legacy of post-Deccan Trap tectonic inversion. In: Mukherjee S, Misra A, Calvès G and Nemèok M (Eds) Tectonics of the Deccan Large Igneous Province Geological Society, London, Special Publications $\mathbf{4 4 5}$ 237-268

Mishra S, Misra S, Vyas D, Nikalje D, Warhade A and Roy S (2017)A 1251 m-thick Deccan Flood Basalt Pile Recovered by Scientific Drilling in the Koyna Region, Western India Journal of the Geological Society of India 90 788-794

Misra A A, Bhattacharya G, Mukherjee S and Bose N (2014) Near N-S paleo-extension in the western Deccan region in India: Does it link strike-slip tectonics with IndiaSeychelles rifting? International Journal of Earth Sciences 103 1645-1680

Misra A A and Mukherjee S (2015) Tectonic Inheritance in Continental Rifts and Passive Margins. Springer briefs in Earth Sciences ISBN 978-3-319-20576-2

Misra A A and Mukherjee S (2017) Dyke-brittle shear relationships in the Western Deccan Strike-Slip Zone around Mumbai (Maharashtra, India) In Mukherjee S,
Misra AA, Calvès G and Nemèok M (Eds) Tectonics of the Deccan Large Igneous Province Geological Society, London, Special Publications 445 269-295

Misra A A, Bhattacharya G, Mukherjee S and Bose N (2014) Near N-S paleo-extension in the western Deccan region, India: does it link strike-slip tectonics with the India Seychelles rifting? International Journal of Earth Sciences 103 1645-1680

Misra AA, Sinha N and Mukherjee S (2015) Repeat ridge jumps and microcontinent separation: insights from NE Arabian Sea Marine and Petroleum Geology 59 406-428

Misra S, Bartakke V, Athavale G, Akkiraju V V, Goswami G and Roy S (2017) Granite-gneiss Basement below Deccan Traps in the Koyna Region, Western India: Outcome from Scientific Drilling Journal of the Geological Society of India $90776-782$

Mukherjee S, Misra A A, Calvès G and Nemèok M (2017) Tectonics of the Deccan Large Igneous Province: an introduction In Mukherjee S, Misra AA, Calvès G, Nemèok M (Eds) Tectonics of the Deccan Large Igneous Province Geological Society, London, Special Publications 445 1-9

Pande K, Yatheesh V and Sheth $\mathrm{H}(2017)^{40} \mathrm{Ar} /{ }^{39}$ Ar dating of the Mumbai tholeiites and Panvel flexure: intense $62.5 \mathrm{Ma}$ onshore-offshore Deccan magmatism during India-Laxmi Ridge-Seychelles breakup Geophysical Journal International 210 1160-1170

Patro P K, Borah U K, Babu G A, Veeraiah B and Sarma S V S (2017) Ground Electrical and Electromagnetic Studies in Koyna-Warna Region, India Journal of the Geological Society of India 90 711-719

Patro P K, Raju K and Sarma S V S (2018) Some Insights into the Lithospheric Electrical Structure in the Western Ghat Region from Magnetotelluric Studies Journal of the Geological Society of India 92 529-532

Patro B P K and Sarma S V S (2007) Trap thickness and the subtrappean structures related to the mode of the eruption in the Deccan Plateau of India: results from magnetotellurics Earth, Planets and Space 59 75-81

Peshwa V V and Kale V S (1987) Role of remote sensing in the detection of potential sites for landslides/rockfalls in the Deccan Trap lava terrain of Western India.In Balasubramaniam Setal. (Eds) Environmental Geotechnics and Problematic Soils and Rocks Balkema Rotterdam; p. 367-374

Peshwa V V and Kale V S (1997) Neotectonics of the Deccan Trap Province: Focus on the Kurduwadi Lineament Journal of Geophysics 18 77-86 
PrajapatiS, Kukarina E and Mishra S (2016) Crustal seismic structure beneath the Deccan Traps area (Gujarat, India), from local travel-time tomography Tectonophysics 672 673 139-149

Radha Krishna M, Verma R K and Purushotham A K (2002) Lithospheric structure below the eastern Arabian Sea and adjoining West Coast of India based on integrated analysis of gravity and seismic data Marine Geophysical Researches $2325-42$

Rajaram M, Anand S P, Erram V C and Shinde B N (2017) Insight into the structure below the Deccan Trap covered region of Maharashtra, India from geopotential data In Mukherjee S, Misra A, Calves G, Nemcok M (Eds) Tectonics of the Deccan Large Igneous Province Geological Society, London, Special Publications $\mathbf{4 4 5}$ 219-236

Rao G S, Kumar M and Radhakrishna M (2018) Structure, mechanical properties and evolution of the lithosphere below the northwest continental margin of India International Journal of Earth Sciences 107 2191-2202

Ravi Kumar M, Singh A, Kumar N and Sarkar D (2015) Passive seismological imaging of the Narmada paleo-rift, central India Precambrian Research 270 155-164

Samant H, Pundalik A, DsSouza J, Sheth H, Lobo K C, D'Souza K and Patel V (2017) Geology of the Elephanta Island fault zone, western rifted margin, and its significance for understanding the Panvel flexure Journal of Earth System Science 12614

Sarkar D and Saein K (2017) Deep Seismic Sounding Experiments in the Koyna RTS Region: An Overview of the Results Journal of the Geological Society of India 90 663-669
Sheth H (2018) Is the Satpura "Horst," in fact, a compressional uplift? Journal of the Geological Society of India 91 391394

Shuhail M, Yatheesh V, Bhattacharya G C, Müller R D, Kamesh Raju KA and Mahender K (2018) Formation and evolution of the Chain-Kairali Escarpment and the Vishnu Fracture Zone in the Western Indian Ocean Journal of Asian Earth Sciences 164 307-321

Sinha D K, Som A and Roy S (2017) The Subsurface Megascopic Characteristics of Basalt and Basement Rocks from KoynaWarna Area of Maharashtra, India Journal of the Geological Society of India 90 761-768

Storey M, Mahoney J J, Saunders A D, Duncan R A, Kelley S P and Coffin M F (1995) Timing of hotspot related volcanism and the breakup of Madagascar and India Science 267852 855

Subbarao K V and Courtillot V (2017) Deccan Basalts in and around Koyna - Warna Region, Maharashtra: Some Reflections Journal of the Geological Society of India 90 653-662

Valdiya K S (2016) The making of India: Geodynamic Evolution $\left(2^{\text {nd }} E d n\right.$.) Springer International $924 \mathrm{p}$

Vanik N, Shaikh H, Mukherjee S, Maurya D M and Chamyal L S (2018) Post-Deccan trap stress reorientation under transpression: Evidence from fault slip analyses from SW Saurashtra, western India Journal of Geodynamics 121 919

Yadav R and Tiwari V M (2018) Numerical simulation of presentday tectonic stress across the Indian subcontinent International Journal of Earth Sciences 107 2449-2462. 